\title{
Rolnictwo w McŚWIECIE
}

\section{Wprowadzenie}

W niniejszym rozdziale dedykowanym Pani Profesor staram się podążać tropem przez Nią wyznaczonym. Pojmując naukę jako służbę społeczną Pani Profesor nie unika trudnych pytań, nie waha się opuszczać wymoszczonych i szerokich traktów obiegowych tez, dostrzega patologie i niebezpieczeństwa, przesłaniane często przez błędne ognie błyskające na bagnach teorii i paradygmatów, uznanych za właściwe i obowiązujące. Daje przykład zachowania intelektualnej suwerenności, zda się zanikającej ${ }^{1}$, i niezłomności w obronie dobra, jakim jest polska wieś i rolnictwo. Ściślej to, co z niej pozostało. Nawiązując do jednego z obszarów zainteresowań i badań Pani Profesor i czerpiąc inspiracje z Jej przemyśleń w niniejszym rozdziale podejmuję namysł nad zagrożeniami w obliczu, których znalazło się rolnictwo, także w naszym kraju. Koncepcje dotyczące wsi i rolnictwa wskazują

na ciągłą dekonstrukcję, nawet erozję konstytutywnych podstaw wsi - rodzinnych gospodarstw, więzi gospodarczych, etosu gospodarczego. (...) Przyjmując optykę postmodernizacji, jeszcze łatwiej przychodzi unieważnienie tych kategorii,

\footnotetext{
${ }^{1}$ Odwołuję się do konstatacji Grażyny Ancyparowicz: „Po pierwsze Polska utraciła suwerenność intelektualną. (...) Polaków pozbawiono już dawno suwerenności intelektualnej (...) Jeżeli do tego media narzucają jedynie słuszne autorytety, a innych wyszydzają, wówczas także elity nie są zdolne do samodzielnej pracy myślowej"; z wywiadu Polska gospodarka jest jak lokomotywa opanowana przez zbieraczy złomu, „Sieci”, 18-24 marca 2013, s. 29-30.
} 


\section{wszelako niestosowna}

wydaje się „lekceważąca stylistyka”, jaka charakteryzuje ogląd wsi w retoryce ekskluzywistycznie miejskiej, obecna w retoryce modernizacji, urbanizacji, industrializacji, transformacji, a ostatnio globalizacji ${ }^{2}$.

Z rozmysłem pomijając wskazaną retorykę i wskazane perspektywy opisu i interpretacji wsi i rolnictwa stawiam w niniejszym rozdziale tezę, iż rolnictwo, także w Polsce, pozostaje już ostatnią, bardzo słabo bronioną i broniącą się flanką, do zdobycia przez McŚwiat.

\section{Co to jest McŚwiat ${ }^{3}$ ?}

McŚwiat „jest niczym innym jak rynkiem”, jego siłę stanowią uniwersalizujące, światowe, niekiedy drapieżne rynki, które tworzy i które są „oparte na konsumpcji i zysku, a kwestie dobra publicznego, o które niegdyś troszczyły się demokratyczne społeczności i ich rządy, pozostawia mało odpowiedzialnej, jeśli wręcz nie fikcyjnej „ręce rynku””4. McŚwiat prowadzi politykę zysku i wiodącymi instytucjami gospodarczymi są w nim korporacje, które można nazwać ponadnarodowymi, postnarodowymi, wręcz antynarodowymi, z pewnością też odgrywają one na arenie międzynarodowej ważniejszą rolę niż państwa ${ }^{5}$. To korporacje dyktują warunki na rynku pracy, siejąc spustoszenie, bowiem

pełne zatrudnienie, choć leży w interesie publicznym, nie leży jednak w interesie korporacji. Wydajność w biznesie narzuca downsizing, co oznacza produkcję z intensywnym udziałem kapitału, czyli politykę zatrudnienia minimalizującą udział siły roboczej

${ }^{2}$ M. Wieruszewska, Kryzys - mit - intuicja. Refleksja nad wsiq - niekoniecznie naukowa, [w:] Socjologia jako służba społeczna, pod red. K. Gorlacha, M. Niezgody, Z. Seręgi, Wydawnictwo UJ, Kraków 2007, s. 89.

${ }^{3}$ Kategorię McŚwiata przyjmuję za Benjaminem Barberem i rekonstruuję na potrzeby tej analizy; por.: B. Barber, Dżihad kontra McŚwiat, Muza, Warszawa 1997.

4 Tamże, s. 38-39, 10-11, 14. Utrata przez państwo kontroli nad rynkiem jest „zagrożeniem zarówno dla sprawiedliwości i polityki społecznej, jak i dla demokratycznej kontroli nad gospodarką w skali całego świata”; tamże, s. 72.

5 Tamże, s. 31. Wielkie korporacje, „których potencjał ekonomiczny przekracza w wielu wypadkach potencjał gospodarczy całych krajów, nawet średniej wielkości, takich jak Polska. (...) potrafią wymóc likwidację czy ograniczenie barier nakładanych przez poszczególne rządy. Najdotkliwszą karą za te utrudnienia i bariery jest brak napływu inwestycji"; por:: J. Wilkin, Polskie rolnictwo i wieś w globalnej przestrzeni - szanse, zagrożenia i mechanizmy dostosowawcze, [w:] Powiq̨zania zewnętrzne. Modernizacja Polski, pod red. W. Morawskiego, Wolters Kluwer, Warszawa 2012, s. 148. 
i skutkującą maksymalnym ograniczeniem liczby stałych pracowników, co redukuje do minimum wydatki na świadczenia i emerytury ${ }^{6}$. Wypychanie z urządzonego przez korporacje rynku pracy kolejnych pracowników prowadzi do wzrostu bezrobocia, które „może w końcu podważyć rynek, bo spadnie liczba potencjalnych konsumentów”, lecz korporacje rywalizujące ze sobą zaciekle „swoje dochody postrzegają najwyżej w perspektywie kwartalnej"7. Polityka korporacji prowadząca do masowej likwidacji miejsc pracy „może budzić dreszcz zgrozy w narodach i państwach, ale rynek z radością uczci zdolność do konkurencji, jaką wykazują uczestnicy gry”" Zatem McŚwiat to nic innego jak Rynek zarządzany poprzez zaciekle ze sobą rywalizujące globalne korporacje, przy czym „kiedy mówimy o światowych firmach i światowych rynkach, do „świata” zaliczają się tylko wyznaczeni uczestnicy gry. Nie chodzi o całą planetę" ${ }^{\prime \prime}$ Fizycznie, głównymi uczestnikami gry są „korporacyjni drapieżnicy”, czyli „niewidzialni prywatni monopoliści, których w odróżnieniu od państwa nie można rozliczyć”, a to oznacza „utrwalenie monopolu w nowej postaci, prywatnej, a więc nie odpowiadającej przed nikim” i stąd „w imperium rynku książętami są chuligani z forsą" ${ }^{10}$. Należy pamiętać, że są oni także beneficjentami prywatyzacji majątku państwowego, której zarówno kult, jak i praktyka sprawowane są od ponad dwudziestu lat w Polsce.

McŚwiat, czyli Rynek urządzony przy wydatnym udziale korporacyjnych drapieżników potrzebuje ludności specjalnego gatunku. Ów pożądany i hodowany właśnie gatunek ludzi ma być pozbawiony cnót obywatelskich, potrzebę wolności ma realizować w supermarkecie ${ }^{11}$, ma być stanowiony przez jednostki „kontaktujące się między sobą przede wszystkim przez transakcje handlowe, w których pojęcie "ja” zastępuje pojęcie „my"”12. W McŚwiecie „każdą nadarzającą się sposobność wykorzystuje się do wpajania nam przeświadczenia, że konsumpcja jest obywatelskim obowiąz-

${ }^{6}$ B. Barber, dz. cyt., s. 36.

7 Tamże.

8 Tamże, s. 42.

9 Tamże, s. 69.

10 Tamże, s. 109, 142-143, 125.

${ }^{11}$ W nietolerującym społeczeństwa obywatelskiego i obywatelskich cnót McŚwiecie świątyniami wolności są restauracje „McDonalda i Kentucky Fried Chicken”; tamże, s. 9-10.

12 Tamże, s. 135, 125. Notabene, pojęcie „my” jest zohydzane m.in. przy pomocy koncepcji nowej plemienności. 
kiem”13. Ponieważ „McŚwiat bardzo sobie ceni infantylizm jako stan umysłu”, dlatego szczególną wagę przywiązuje do kreacji obrazu rzeczywistości i „dziś prawdziwa bitwa toczy się o to, kto będzie kontrolował obrazy tego świata, a co za tym idzie sprzedawał określony styl życia, kulturę, produkty i idee"14. Bitwę tę toczą między sobą koncerny medialne, twory McŚwiata utrwalające i rozprzestrzeniające go. Nie dziwi, że scharakteryzowany wyżej McŚwiat ceni infantylizm jako stan umysłu i największą wagę przywiązuje do narzucania stosownych obrazów świata, wzorów myślenia i życia, bowiem racjonalność, dojrzałość umysłowa i odpowiadające temu postępowanie, poczynając od solidarnego współdziałania na rzecz ochrony rynku pracy i państwowej własności zasobów, oznaczałoby początek jego końca.

Pisany z dużej litery Rynek - synonim i kwintesencja McŚwiata - to rzeczywistość, w której właśnie żyjemy, której zasadom w rosnącym stopniu podlegamy. Obejmuje on stopniowo cały świat systematycznie prywatyzując, komodyfikując i spieniężając wszystko, co się da. McŚwiat z jego zasadami należy uznać za wyraz degeneracji naszej cywilizacji, a ich rozprzestrzeniane za czynnik degeneracji kolejnych społeczeństw i gospodarek $^{15}$. W McŚwiecie nie odżywa też stara zasada laissez-faire ${ }^{16}$. Urządzony i zdominowany przez globalne korporacje i korporacyjnych drapieżników Rynek jest osobliwym wolnym rynkiem. Z jednej strony, ma miejsce zaciekła rywalizacja pomiędzy korporacjami-gigantami, dążącymi do wyeliminowania konkurencji i zmonopolizowania danej branży. Skutkiem tego jest stale postępująca monopolizacja i oligarchizacja wszystkich rynków McŚwiata. Z drugiej strony, elementy wolnego rynku, czyli wolnej gry rynkowej nie obliczonej na zniszczenie konkurencji trwają, jeszcze, w niszach gospodarczych i dotyczą małych podmiotów ${ }^{17}$. W najlepszym przypadku sytu-

${ }^{13}$ J. Perkins, Hitman. Wyznania ekonomisty od brudnej roboty, Studio Emka, Warszawa 2006, s. 16. „Większość gazet, czasopism i wydawnictw jest własnością i podlega manipulacji przez wielkie międzynarodowe korporacje. Nasze media stanowią integralną część korporacjokracji"; tamże, s. 267.

14 B. Barber, dz. cyt., s. 118, 105.

${ }^{15}$ W odmiennej opinii Barbera: „sił McŚwiata nie da się (...) powstrzymać, bo to na nich opiera się powolna, lecz nieuchronna ofensywa zachodniej cywilizacji; tamże, s. 27.

${ }^{16}$ Co twierdzi B. Barber, tamże, s. 42.

17 Inaczej rzecz ujmuje D. Korten pisząc, że wielkie korporacje zarządzają konkurencją, co polega na „ograniczaniu współzawodnictwa między nimi” i zachęcaniu do współzawodnictwa mniejsze podmioty; D. Korten, When the Corporation Rule the World, Kumarin, New York 1995, cytuję za: K. Gorlach, Socjologia obszarów wiejskich. Problemy i perspektywy, Wydawnictwo Scholar, Warszawa 2004, s. 213. 
ację tę można określić mianem dualizmu, ponieważ rynkami McŚwiata rządzą jednak monopoliści. Narzucają oni reguły stałego wzrostu i stałej morderczej konkurencji zasadzie tej podporządkowując wszelkie obszary aktywności, poczynając do sfery gospodarczej, na społeczno-kulturowej kończąc.

Władzę globalnych antypaństwowych korporacji współkreujących McŚwiat można - odwołując się do określenia i ustaleń Johna Perkinsa nazwać korporacjokracją ${ }^{18}$. Jest to stan, w którym rzeczywistą władzę gospodarczą, a z nią i polityczną, mają korporacje dyktujące reguły działania w obydwu tych sferach. Korporacjokrację zaprowadzają na świecie „ekonomiści od brudnej roboty” (EBR-owcy). Będący kiedyś jednym z nich J. Perkins przedstawia się następująco: „stanowimy elitarną grupę ekspertów wykorzystujących środki międzynarodowych organizacji finansowych do tworzenia warunków, w których inne narody zostają podporządkowane największym korporacjom, naszemu rządowi i naszym bankom. Podobnie jak mafia EBR-owcy oferują swoim partnerom określone korzyści. Przybierają one formy pożyczek na rozbudowę infrastruktury (...) a przyznawane są jedynie pod warunkiem, że wszystkie finansowane z nich obiekty zostaną zaprojektowane i wybudowane przez nasze firmy"19. W rezultacie,

gotówka wraca niemal natychmiast do firm tworzących korporacjokrację (kredytodawcę), kraj otrzymujący kredyt musi spłacić go w całości wraz z odsetkami. EBR owiec odnosi pełny sukces, gdy kredyty są tak duże, że po kilku latach kredytobiorca nie jest zdolny spłacić kolejnych rat. A wtedy my, jak mafia, zgłaszamy się po nasz łup. Przybiera on różne formy: przejęcie głosu danego kraju w głosowaniach na forum ONZ, instalacja baz wojskowych, lub uzyskanie praw do korzystania z zasobów naturalnych danego kraju. (...) Oczywiście kredy tobiorca nadal pozostaje naszym dłużnikiem, a kolejny kraj zostaje wchłonięty przez nasze globalne imperium ${ }^{20}$.

\section{Co najistotniejsze, trwanie i rozwój tego imperium}

zależy od skutecznego współdziałania wielkich banków, korporacji i rządów - części składowych korporacjokracji - lecz nie ma to nic wspólnego ze spiskiem ${ }^{21}$. Korporacjokracja to my (...) większość z nas pracuje dla tych banków, korporacji lub rządów

\footnotetext{
${ }^{18}$ J. Perkins, $d z$. cyt. passim.

19 Tamże, s. 21.

20 Tamże, s. 21-22. Siedziba korporacjokracji, czyli McŚwiata mieści się w krajach centrum, chociaż sam J. Perkins na pierwszym miejscu sytuuje Stany Zjednoczone.

21 Tamże, s. 16.
} 
lub w jakiś sposób zależy od nich ze względu na produkowane przez nie dobra.

Nie możemy pozwolić sobie na gryzienie ręki, która nas karmi²2.

Godnym uwagi jest wskazany fakt, że częścią korporacjokracji stają się rządy podejmujące współpracę z wielkim kapitałem i antypaństwowymi korporacjami. Tym samym ponoszą one odpowiedzialność za wykreowaną rzeczywistość i jej skutki dla państwa i obywateli, którzy powierzyli im władzę.

Warunkiem sine qua non zaistnienia i rozwoju korporacjokracji, będącej jeszcze jednym imieniem McŚwiata, jest globalizacja. Korporacjokracja -McŚwiat powstaje w skali globalnej, a w jego przestrzeń wchłanianie są, za pomocą opisanego mechanizmu, kolejne regiony i kraje. Globalizacja to główny nerw opisywanego porządku. Tylko w warunkach globalizacji możliwe było zbudowanie ponadnarodowych korporacji i ich potęgi ekonomicznej i politycznej i tylko w warunkach globalizacji mogą one wywierać taki wpływ na rządy państw narodowych. Sama globalizacja też nie jest dziełem przypadku, lecz rezultatem podjętych i podtrzymywanych decy$\mathrm{zji}^{23}$. Ma też swoich stałych i potężnych promotorów. Są nimi międzynarodowe organizacje - Międzynarodowy Fundusz Walutowy (MFW), Bank Światowy (BŚ), Organizacja Współpracy Gospodarczej i Rozwoju (OECD), Światowa Organizacja Handlowa (GATT) - dysponujące

wieloma instrumentami wpływu, nie tylko o charakterze finansowym. Wszystkie one za swój główny cel przyjęły liberalizację handlu, ograniczanie przeszkód w przepływie kapitału i upodabnianie zasad prowadzenia działalności gospodarczej ${ }^{24}$.

Te zasady zbudowały i umacniają obecną ekonomiczną i polityczną potęgę ponadnarodowego kapitału i korporacji, działając wyłącznie w interesie silnych aktorów Rynku, kosztem słabszych podmiotów, w tym państw² ${ }^{25}$.

${ }^{22}$ Tamże, s. 263; dalej autor pyta retorycznie: „w jaki sposób sprzeciwić się systemowi, który zapewnia ci dom, samochód, jedzenie, ubranie, energię elektryczną i opiekę zdrowotną?"; tamże.

${ }^{23}$ Nic innego ,jak podjęcie decyzji o odejściu od: protekcjonizmu w handlu, zaawansowanego interwencjonizmu państwowego oraz ideału państwa opiekuńczego (...) zapoczątkowały radykalną zmianę. (...) I to właśnie owa decyzja (...) staje się nową, potężną siła napędową procesu globalizacji"; K. Romaniszyn, Globalizacja - proces żywiołowy czy sterowany?, [w:] Problemy cywilizacyjne naszej współczesności, pod red. J. Gąssowskiego, J. Goćkowskiego, K. Machowskiej, Akademia Humanistyczna, Pułtusk 2007, s. 102.

${ }^{24}$ J. Wilkin, dz. cyt., s. 149.

25 „Globalizacja wzmacnia pozycję rynku i globalnych podmiotów gospodarczych, zagraża natomiast autonomii i sile państwa"; tamże, s. 150. 
Politycy większości krajów nie podejmują decyzji „wzbudzających niechęć” MFW, BŚ i korporacji międzynarodowych, bo „któryż z polityków, poza nielicznymi przypadkami dyktatur, może sobie pozwolić na posunięcia” niechęć tę wzbudzające ${ }^{26} \mathrm{~W}$ ten sposób urzeczywistnia się faktyczny dyktat rzeczonych instytucji i wspieranych przez nie antypaństwowych korporacji. Potencjał ekonomiczny tych ostatnich „rośnie bardzo szybko. Następuje koncentracja kapitału finansowego”, a wraz z nią ma miejsce kolejny etap „wykorzenienia się systemu gospodarczego z systemu społecznego, a także politycznego" 27 . Owo wykorzenienie oznacza nie tylko rosnącą autonomię ponadpaństwowych podmiotów globalnej gospodarki i, popierających stały wzrost ich potęgi, instytucji, lecz także stopniowe przejmowanie przez wszystkich wymienionych władzy nad państwami, a tym samym nad całym światem. To właśnie jest McŚwiat powstały dzięki globalizacji realizowanej wedle wskazanych zasad i legitymizowany przez „fundamentalizm rynkowy," ${ }^{28}$ czyli pogląd ekonomiczny odpowiadający interesom wielkiego kapitału i ponadnarodowych, antypaństwowych korporacji. Fundamentalizm rynkowy legitymizujący McŚwiat pozostaje w przedziwnej symbiozie z protekcjonizmem, ale selektywnym, bo obejmującym tylko gigantów $^{29}$. Działania promotorów takiej globalizacji, czyli MFW i pozostałych instytucji, można za Josephem Stiglitzem uznać za „nowe wcielenie mentalności kolonialnej”30. Również w nowym wcieleniu mentalność kolonialna działa na rzecz kolonizacji, drogę ściele jej neoliberalna globalizacja, narzędziem jest Rynek wspierany przez fundamentalizm rynkowy, a beneficjentami są korporacje, wielki kapitał i rządy współpracujące z nimi przeciw własnym obywatelom i krajowi. Nowej mentalności kolonialnej doby globalizacji odpowiadają nowe rezultaty, czyli kolonizacja zasobów i bogactw całej Ziemi zubażająca bądź spychająca w ubóstwo całe społeczeństwa. Już obecnie wyraża się to w przejęciu znacznej części światowych zasobów i kapitału przez kilkaset największych korporacji i kilkaset najbogatszych

26 Tamże, s. 149.

27 Tamże, s. 150.

${ }^{28}$ J. Stiglitz, Globalizacja, PWN, Warszawa 2004, s. 197.

29 Czym jak nie McŚwiatowym selektywnym protekcjonizmem jest praktyka zwalniania międzynarodowych sieci handlowych czy instytucji finansowych z płacenia podatków, bezwzględnie egzekwowanych od pozostałych podmiotów gospodarczych, a w UE tolerowanie pomocy państwowej dla niemieckich, ale już nie dla polskich stoczni?

${ }^{30}$ J. Stiglitz, dz. cyt., s. 48. 
rodzin - ponad połowa ze stu największych gospodarek świata to wielkie ponadnarodowe korporacje ${ }^{31}$. Taki sposób akumulacji kapitału prowadzi do nowych podziałów społecznych, powstaje nowa klasa panująca stanowiona przez zarządy międzynarodowych instytucji, korporacji i współdziałające z nimi rządy państw i klasa zdominowana stanowiona przez pracowników o niskich kwalifikacjach, członków podklasy i społeczeństwa marginalizowane $^{32}$. To jest McŚwiat, gdzie „nie tylko bogaci bogacą się coraz bardziej, a biedni ubożeją, ale bogaci mają coraz więcej swobody, biedni zaś popadają w niewolę"33. Jest to nasz McŚwiat, gdzie „nieliczni opływają w bogactwa, a większość ludzi pogrąża się w nędzy, przemocy i cierpi z powodu zanieczyszczenia środowiska"34. Na rzecz McŚwiata, z właściwym mu chciwym mnożeniem zysków przez nielicznych i maksymalną eksploatacją zasobów Ziemi ${ }^{35}$, pracują m.in. ekonomiści od brudnej roboty „wykorzystywani przez gospodarczą machinę zaprogramowaną na wysysanie światowych zasobów oraz utrwalanie niewolnictwa" ${ }^{36}$. W czym bardzo pomocne, jako mechanizm zniewalania, trwałego uzależnienia i wyzyskiwania państw i społeczeństw okazują się kredyty inwestycyjne, tak w Polsce cenione.

W odwołaniu do wskazanych cech definiuję McŚwiat jako sposób zorganizowania rzeczywistości wpierw gospodarczej, a następnie społecznej i kulturowej, którego zasadą naczelną jest przejęcie i utowarowienie wszystkich zasobów dla maksymalnego zysku i maksymalnej koncentracji władzy, ekonomicznej i politycznej, nielicznych. McŚwiat nie jest ani żywiołowym procesem, ani rezultatem takiego procesu, jest kreacją zainteresowanych taką właśnie organizacją świata. Do tego gremium należą BŚ, MFW i inne instytucje aktywnie wspierające proces globalizacji, ponadnarodowe korporacje, instytucje finansowe, rządy niektórych państw. McŚwiat, czyli opisany sposób zorganizowania rzeczywistości, też nie rozszerza się żywio-

${ }^{31}$ D. Korten, dz. cyt., cytuję za: K. Gorlach, Socjologia obszarów wiejskich, s. 212.

32 L. Sklair, Sociology of the Global System, Prentice Hall, London 1995.

33 B. Barber, dz. cyt., s. 71.

34 „Ponad połowa ludności świata żyje za równowartość niecałych dwóch dolarów dziennie - mniej więcej tyle samo mieli do dyspozycji na początku lat 70-tych. Jednocześnie jeden procent najbogatszych mieszkańców tych krajów posiada od 70\% do $90 \%$ bogactw i nieruchomości"; por.: J. Perkins, dz. cyt., s. 23.

${ }^{35}$ McŚwiat przesłania eksploatację społeczeństw i Ziemi za pomocą argumentu o przeludnieniu, które rzekomo zagraża światu i mocą tego argumentu narzuca krajom biednym przymus i metody kontroli urodzeń.

${ }^{36}$ J. Perkins, dz. cyt., s. 17. 
łowo, lecz jest rozszerzany przez wskazane gremia i współpracujących z nimi lokalnych beneficjentów forsowanych rozwiązań i porządku, również prawnego w kolejnych krajach, regionach i sferach życia, w tym w rolnictwie.

Przedstawiona koncepcja McŚwiata daje możliwość krytycznej analizy współczesnego społeczeństwa i gospodarki urządzanych przez praktykę liberalizmu i sakralizowanych przez jego ideologię. Wytwarzane w akademiach koncepcje, szczególnie te objaśniające świat w duchu materializmu historycznego czy neoewolucjonizmu, orzekające następowanie po sobie kolejnych faz rozwoju gospodarki i społeczeństwa, analizy takiej nie ułatwiają, lecz dostarczają uzasadnień i naukowej legitymizacji wprowadzanych zmian. Identyfikowanie rzeczywistości jako kolejnej, zatem naturalnej, fazy toczącego się procesu skłania do uznania tego, co się obserwuje za li tylko specyfikę obecnego „etapu” rozwoju ${ }^{37}$ i może odwodzić od nazywania dostrzeganych zagrożeń, analizowania ich przyczyn i poszukiwania środków zaradczych. Koncepcje te wraz z ideologią liberalizmu mogą skutecznie zamulić intelekt niekiedy także tych, którzy są zobowiązani i powołani do rozpoznawania i wskazywania zagrożeń dla społeczeństwa, gospodarki i państwa. Zaproponowana perspektywa McŚwiata skłaniająca do krytycznej analizy rzeczywistości może okazać się alternatywą dla wskazanych interpretacji.

\section{Rolnictwo w McŚwiecie}

McŚwiat nie omija rolnictwa, narzucając mu swoje zasady organizacji i podporządkowując je sobie. Rezultatem jest: tworzenie latyfundiów na gruntach rolnych przejmowanych różnymi sposobami od dotychczasowych użytkowników lub właścicieli, ich komodyfikowanie tam, gdzie - jak w krajach afrykańskich - ziemia nie była dotąd towarem, towarzyszące temu komodyfikowanie pracy na roli, czyli przekształcanie rolników w najemnych robotników rolnych pozbawionych innych możliwości zarabiania na utrzymanie $^{38}$. Rezultatem podporządkowywania rolnictwa McŚwiatu, i wskaźnikiem tego, jest również komodyfikacja płodów rolnych, traktowanych nie jak żywność-pokarm, lecz jak towary-rzeczy obliczone na maksy-

${ }^{37}$ W tym duchu mówi się na przykład o przejściu kapitalizmu z fazy narodowej w fazę ponadnarodową, czy wkroczeniu rolnictwa w fazę postprzemysłową.

${ }^{38}$ Notabene, pojawiają się już sygnały o podobnej sytuacji w Polsce, mającej miejsce w potworzonych po 1989 roku wielkich majątkach ziemskich. 
malny zysk, a zatem masowo produkowane i przetwarzane - bez różnicy czy na pożywienie czy na biopaliwo ${ }^{39}$ - masowo sprzedawane lub masowo niszczone, gdy sprzedaż zostaje uznana za nieopłacalną. Wyrazem porządkowania rolnictwa wedle zasad McŚwiata, zorientowanych na osiąganie maksymalnego zysku przez „chuliganów z forsą”, jest genetyczne modyfikowanie roślin (GMO) i forsowanie ich upraw zapewniające zbyt takich nasion oraz inżynieria genetyczna, $w$ tym produkcja biopaliw de facto przyspieszająca zmiany klimatu, którym ma rzekomo zapobiegać ${ }^{40}$. McŚwiat nie zostawia miejsca dla wsi i chłopskiego gospodarstwa. Wprawdzie toleruje jeszcze małą i średnią własność ziemi i małe gospodarstwa rolne, lecz już obecnie ich właścicielom wyznacza rolę producentów towaru dla koncernów monopolizujących przetwórstwo produktów rolnych bądź ich zbyt ${ }^{41}$. W rolnictwie zorganizowanym przez McŚwiat, gdzie wszystko, z ludźmi włącznie, jest towarem, bezpieczeństwo żywnościowe i jakość żywności, rolnik i jego praca, konsument i jego zdrowie, wreszcie człowiek i jego życie nie znaczą nic. Liczy się nieograniczony zysk globalnych graczy, opanowujących właśnie ten sektor gospodarki w kolejnych państwach.

W Unii Europejskiej świadomość konieczności obrony rolnictwa przed Rynkiem jest udziałem zarówno pojedynczych państw takich jak Francja czy Niemcy, które z determinacją chronią swoje rolnictwo, jak i Wspólnoty jako całości, czego wyrazem jest wypracowana Wspólna Polityka Rolna. Jej celem jest zapewnienie samowystarczalności żywnościowej traktowanej jako „istotny element bezpieczeństwa krajów członkowskich”42 i ochrona gospodarstw rodzinnych. Instrument ten nie niweluje wszelako ani ostrej rywalizacji o środki pomiędzy krajami członkowskimi, ani nie zapobiega nierównemu traktowaniu rolników z poszczególnych krajów. Można odnieść wrażenie, że o wyniku tych zmagań decydują pospołu wola i determinacja danego rządu $\mathrm{w}$ obronie rodzimego rolnictwa ${ }^{43}$ i ranga danego państwa

${ }^{39}$ Obecnie „prawie połowa uprawianych zbóż przeznaczana jest na pasze i paliwa” a „skala spekulacji na surowcach i żywności osiągnęła gigantyczne rozmiary"; J. Szewczyk, Krwiożercze bliźniaki rządzą światem, „W Sieci” 4-10 luty 2013, s. 86.

${ }^{40}$ Odpowiedzią McŚwiata na zachodzącą koincydencję między wzrostem produkcji biopaliw i wzrostem cen żywności, jest umasowienie upraw GMO!

${ }^{41}$ Obserwowaną w tej sferze praktyką, także w Polsce, jest wymuszane kredytowanie, czyli zaleganie przez wielkie sieci handlowe z należnościami dla rolników, dostawców produktów rolnych.

${ }^{42}$ K. Gorlach, Socjologia obszarów wiejskich, s. 220.

43 Taka wola i determinacja świadczy o danym państwie: „we wszystkich krajach rozwiniętych rolnicy są chronieni i wspierani przez państwo", chociaż rozmiary wsparcia są różne; 
w Unii. Powstanie wspólnej polityki rolnej to po części rezultat doświadczeń, by nie powiedzieć eksperymentów, zdobytych w ciągu dziesięcioleci wcielania w życie kolejnych modeli rolnictwa ${ }^{44}$. Ich rezultatem jest przekonanie, że rolnictwo nie może zostać „podporządkowane wyłącznie rynkowi”, ponieważ spełnia ono również „wiele funkcji pozaprodukcyjnych” dotyczących społeczeństwa, kultury, przyrody ${ }^{45}$. Tym samym w Unii Europejskiej „rolnika zaczyna się postrzegać jako gospodarza - strażnika zasobów naturalnych, cennych w wymiarze planetarnym, a także jako „powiernika tradycji kulturowych narodu"'46. Przyjęta optyka jest, w rzeczy samej, wyborem aksjologicznym, w którym takie wartości jak tradycja, kultura, trwanie całej warstwy społecznej zostały uznane za cenniejsze niż maksymalny, doraźny zysk „chuliganów z forsą”. W McŚwiecie tertium non datur. Ten wybór nie jest próbą „ucywilizowania” Rynku ${ }^{47}$, lecz próbą przeciwstawienia się Rynkowi, który nie podlega ucywilizowaniu i albo to on pochłonie świat, jaki znamy, albo będzie stale i wielkim wysiłkiem mitygowany, albo co wydaje się najmniej prawdopodobne - sam upadnie. Przeciwstawianie się Rynkowi wymaga wielkiej determinacji, oprócz innych cnót, bowiem unijne aksjologiczne wybory nie osłabiły zapędów kolonizacyjnych i towarzyszącej im stałej i silnej presji McŚwiata na rządy państw Wspólnoty. Wręcz przeciwnie. Wspólna Polityka Rolna niezmiennie wzbudza niezadowolenie wiodących instytucji Rynku, globalizujących świat, czyli Banku Światowego, Międzynarodowego Funduszu Walutowego, Światowej Organizacji

\footnotetext{
J. Wilkin, dz. cyt., s. 145. Zabiegi naszych rządów i ich rezultaty nie wskazują ani na wysoką rangę naszego kraju, ani na jego rozwój, ani na determinację władz państwowych by bronić polską wieś i rolnictwo, gdy w UE „w dziedzinie rolnictwa toczy się (...) gra i walka interesów między poszczególnymi państwami; (...) niejednokrotnie całkowicie sprzecznych”; L. Staszyński, Wieś na wstecznym biegu, Wyd. KMS ResCon, Warszawa 2010, s. 70.

${ }^{44}$ Następujące po sobie, kolejno wdrażane „pomysły na rolnictwo” nazywam metodą prób i błędów. Były to: model agroindustrialny upatrujący w rolnictwie "fabrykę żywności” i zalecający jego zmechanizowanie, uprzemysłowienie i maksymalną produktywność; model post-produkcyjny preferujący świadczenie „zielonych usług” przez obszary wiejskie; aktualnie promowany model rozwoju zrównoważonego zakładający ochronę i trwały, wielostronny rozwój lokalnego środowiska, gospodarki i społeczności; podaję za: T. Adamski, K. Gorlach, Koncepcja rozwoju neoendogennego, czyli renesans znaczenia wiedzy lokalnej, [w:] Socjologia jako służba społeczna. Sukcesja tych modeli nie oznacza, że wraz z modelem odrzucono praktykę, w każdym razie w Polsce one współwystępują.

45 J. Wilkin, dz. cyt., s. 147.

${ }^{46}$ M. Wieruszewska, dz. cyt., s. 92.

${ }^{47}$ Parafrazuję konstatację M. Wieruszewskiej; tamże.
} 
Handlu, które stale poddają ją krytyce i naciskają na ograniczenie ochrony europejskiego rolnictwa ${ }^{48}$. Można mieć pewność, że zachłanność Rynku i „chuliganów z forsą” nie zatrzymała się u bram Unii. Konkretne, antynarodowe korporacje poszukują i znajdują drogi przenikania do rolnictwa poszczególnych krajów UE. Jedną z nich jest agrobiznes bez wątpienia sprzyjający urządzaniu rolnictwa wedle zasad McŚwiata, także w krajach członkowskich UE.

Składnikami agrobiznesu - który należy uznać za wytwór Rynku, podlegający jego prawom - są: „podmioty związane z różnymi fazami wytwarzania żywności: od przemysłów zaopatrujących rolników w środki produkcji do supermarketów"49. Proces koncentracji zachodzi w agrobiznesie „najsilniej poza sektorem bezpośredniej produkcji rolnej”, w rezultacie z wielką ilością gospodarstw współdziała „stosunkowo niewiele potężnych korporacji kontrolujących ważne dziedziny agrobiznesu", a producenci rolni są coraz mocniej podporządkowywani wielkim korporacjom działającym „w otoczeniu rolnictwa"50. Jest to rzeczywista kontrola polegająca na: opanowaniu newralgicznych dziedzin agrobiznesu, wytwarzaniu opatentowanych produktów i technologii, wymuszaniu dla nich akceptacji ${ }^{51}$ oraz dyktowaniu narodowych i międzynarodowych porozumień handlowych ${ }^{52}$. Przejmowanie przez kilka korporacji kontroli nad wybranymi segmentami rynku rolnego, ich monopolizacja i globalizacja odbywają się zgodnie z zasadą działania McŚwiata. Przykładem oligopolizacji na rynku rolnym ${ }^{53}$, prowadzącej do dyktatu cen ${ }^{54}$, jest zdominowanie światowego rynku nasion „przez takie firmy, jak Monsanto, Syngenta, Du Pont oraz Aventis” czy fakt, że na czele „trzech wielkich i dominujących w globalnym łańcuchu przemysłu spożywczego sieci" stoją korporacje Cargill i Monsanto, ConAgra i Novartis, Archer

${ }^{48}$ J. Wilkin, dz. cyt., s. 145.

49 Tamże, s. 143.

50 Tamże, s. 144. Na przykład, wielkie korporacje w 67 procentach kontrolują produkcję i dostaw nasion, a w 89 procentach produkcję środków agro-chemicznych; tamże.

${ }^{51}$ Opatentowanie i narzucanie opatentowanych produktów i technologii daje gwarancję kolosalnych zysków i władzy nad producentami żywności. Co więcej, jeśli nasiona roślin GMO, które muszą być zakupione, wysieją się samorzutne na sąsiednich polach, skutkuje to procesami, ponadto gospodarstwo jest karane za złamanie deklaracji o czystości swoich produktów.

52 J. Wilkin, dz. cyt., s. 144.

53 Taką diagnozę stawia Krzysztof Gorlach, Socjologia obszarów wiejskich, s. 98.

${ }^{54}$ Dominacja agrobiznesu w gospodarce żywnościowej sprawia, że rolnik „uzyskuje niższą cenę", a konsument „płaci więcej niż byłoby to w systemie swobodnej konkurencji”; tamże, s. 213. 
Daniels Midland ${ }^{55}$. W rolnictwie organizowanym przez McŚwiat, zasadnie nazywanym superindustrialnym, producentem rolnym nie jest chłop, rolnik, farmer czy przedsiębiorca, lecz agrobiznesmen prowadzący duży rolny biznes przy udziale zewnętrznego kapitału i najemnej siły roboczej ${ }^{56}$. Jest to biznes całkowicie zależny od pożyczki, zwykle bankowej, i od podaży rąk do pracy, czyli od sytuacji na lokalnym rynku pracy, na który wpływ ma nie agrobiznesmen, lecz globalne korporacje. Wynika stąd, że w rzeczywistości McŚwiata także niezależność i zdolność trwania biznesu agrobiznesmena jest iluzoryczna i podlega prawu Rynku, którym jest maksymalizacja profitów przez głównych graczy. W porównaniu z biznesem agrobiznesmena, chłopskie gospodarstwo rodzinne prosperujące dzięki własnemu kapitałowi i własnej pracy członków tegoż gospodarstwa, zachowuje niezależność i nie przynosi „chuliganom z forsą” oczekiwanych zysków, dlatego jest dla Rynku zawadą.

Kolejnym wyrazem podporządkowywania rolnictwa McŚwiatu jest powstanie i rozwój przemysłu żywności ${ }^{57}$ dopełniającego komodyfikację płodów rolnych. Powstanie tego przemysłu sprawia, że żywność wytwarzana w gospodarstwach przyjmuje „wartość surowca przemysłowego" ${ }^{{ }^{58}}$ do „produkowania rozmaitych artykułów spożywczych," ${ }^{59}$ a „rodziny rolnicze przestają być „wolnymi twórcami chleba”, a stają się producentami surowców dla różnych działów przemysłu"60, o ile zdołają zainteresować swoimi produktami nabywców czyniących masowe zakupy. Jeśli ci ostatni zdominują lokalny rynek produktów rolnych, wówczas indywidualni producenci wytwarzający żywność w umiarkowanych ilościach mają trudności z jej zbytem tak, że niektórzy z nich poszukują nowych dróg dotarcia do konsumentów ${ }^{61}$. Tworzony w McŚwiecie przemysł żywności jest, jak wszystko,

55 Tamże, s. 230. Ponadnarodowe korporacje w rosnącym stopniu kontrolują także sprzedaż żywności, w USA 40 procent „artykułów spożywczych znajduje się pod kontrolą pięciu wielkich sieci supermarketów (...) w Australii 75 \% rynku produktów żywnościowych kontrolują tylko trzy wielkie sieci"; tamże.

56 Tamże, s. 79 i 98.

57 Przyjmuję taką nazwę, by podkreślić, że ów przemysł traktuje żywność wyłącznie jak towar-rzecz, a nie jak towar-pokarm.

${ }^{58}$ L. Kocik, Anomia moralno-obyczajowa wsi polskiej, [w:] Kondycja moralna społeczeństwa polskiego, pod red. J. Mariańskiego, WAM, Kraków 2002, s. 93.

59 K. Gorlach, Socjologia obszarów wiejskich, s. 218.

${ }^{60}$ L. Kocik, Między przyrodq, zagrodq i społeczeństwem, Wydawnictwo UJ, Kraków 2000, s. 112.

${ }^{61}$ Przykładem są powstające w Polsce sklepy internetowe, w których można zamówić żywność z konkretnego gospodarstwa, cieszą się one rosnącym zainteresowaniem konsumentów. 
globalny ${ }^{62}$. Produkty dla globalnego przemysłu żywności są wytwarzane, na masową skalę i z przeznaczeniem na eksport, głównie w krajach trzeciego świata. Zorientowanie rolnictwa tych krajów na masową i eksportową produkcję prowadzi do powstania monokulturowego systemu wytwórczego, na przykład „wołowiny w niektórych regionach Ameryki Łacińskiej czy owoców tropikalnych w basenie Morza Karaibskiego lub Afryce", skutkującego zanikiem samowystarczalności żywnościowej wielu z nich, co podważa bezpieczeństwo żywnościowe tamtejszej ludności, szczególnie kategorii uboższych ${ }^{63}$. W krajach tych wskutek przeznaczania wytwarzanej żywności na eksport dochodzi, bowiem do zerwania „więzi między lokalną czy regionalną produkcją a potrzebami lokalnej czy regionalnej populacji”64. Powstanie przemysłu żywności i globalnego rynku rolno-spożywczego sprawia, że

kraje rozwijające się orientują swoją gospodarkę rolną i żywnościową na rzecz wymogów rynku globalnego (...) natomiast kraje wysoko rozwinięte upłynniają $\mathrm{w}$ formie dumpingowej swoje wewnętrzne zapasy ${ }^{65}$.

Wskazany sposób urządzania rolnictwa przez McŚwiat nazywany jest restrukturyzacją. Jej warunkiem jest umiędzynarodowienie gospodarek narodowych wraz z towarzyszącym mu nowym międzynarodowym podziałem pracy ${ }^{66}$, którego sens oddał powyższy cytat. Powstanie i rozwój globalnego przemysłu żywności oznacza zawładnięcie przez McŚwiat kolejnym segmentem rolnictwa. Retoryczne jest pytanie, czy celem tego przemysłu pozostaje jakość artykułów spożywczych ${ }^{67}$ i bezpieczeństwo żywnościowe czy zysk. Dążenie do niego dokonuje się nawet za cenę nędzy całych społeczności. Pouczającego przykładu dostarcza historia uprzemy-

${ }^{62}$ W literaturze mówi się o globalizacji gospodarki żywnościowej, czyli zintegrowaniu w skali globalnej wytwarzania, przetwarzania i dystrybucji żywności; K. Gorlach, Socjologia obszarów wiejskich, s. 234.

63 Tamże, s. 229, 233.

64 Tamże, s. 231.

65 Tamże, s. 229.

${ }^{66}$ Zgodne z paradygmatem restrukturyzacji wycofanie się państwa z regulacji gospodarki narodowej, w praktyce nie wyklucza zaangażowania elit politycznych $w$ tę restrukturyzację i czerpania z niej profitów.

67 Produkowana przemysłowo żywność jest nie tylko niskiej jakości, lecz bywa wręcz trująca. Standardem jest używanie w tym przemyśle produktów hodowli hormonalnej i GMO, konserwantów, wypełniaczy, zdarzają się też: antybiotyki, perhydrol, emulgatory, dioksyny i itp. oraz zepsute i przeterminowane półprodukty. 
słowienia tradycyjnego rybołówstwa w akwenie jeziora Wiktorii w Afryce. Stanowiło ono podstawę utrzymania i diety lokalnych społeczności Ugandy, Kenii, Tanzanii, które rocznie odławiały ok. 100000 ton ryb sprzedawanych na lokalnym rynku ${ }^{68}$. Uprzemysłowienie tego rybołówstwa rozpoczęto, u schyłku lat 50. dwudziestego wieku, od zarybienia jeziora obcym mu gatunkiem gigantycznej ryby, co spowodowało wzrost połowów do ok. 500000 ton rocznie, pomnożenie liczby łodzi i powstanie licznych nowych miejsc pracy. W latach 80., pojawiają się tu nowi aktorzy, czyli wielki biznes z Afryki Wschodniej, ponadnarodowe korporacje i międzynarodowe banki, co prowadzi do powstania 50 dużych fabryk produkujących standardowe filety na eksport ${ }^{69}$. Giną tradycyjne rybołówstwo i lokalny rynek ryb, cena za ryby wyklucza je z diety miejscowej ludności, postępuje pauperyzacja indywidualnych rybaków i ich masowa migracja do slumsów najbliższych metropolii. Beneficjentami uprzemysłowienia są inwestorzy, właściciele flotylli i fabryk, eksporterzy, reprezentanci lokalnej klasy politycznej, ofiarą jest lokalna społeczność spauperyzowana i wyrugowana ze swoich wiosek. Tak, oto, Rynek i lokalne rządy zrestrukturyzowały tradycyjne rybołówstwo, objawiając przy okazji istotę tego zabiegu. W globalizowanym świecie ów, z pozoru odległy, afrykański przypadek stanowi memento, także dla nas. Pokazuje on, że restrukturyzacja to $\mathrm{w}$ istocie zamiana właścicieli bądź użytkowników zasobów. McŚwiatowego urządzania rolnictwa kolejnych krajów nie powstrzymują jego skutki, jakimi są przekształcenie: lokalnego rolnictwa w system monokulturowy, rolników w robotników rolnych, zwykle spauperyzowanych, żywności w towar-rzecz oraz podporządkowanie monokulturowych systemów krajom wysoko rozwiniętym. Urządzanie rolnictwa przez McŚwiat podlega zasadzie cechującej ten zaprowadzany globalnie porządek, czyli przejmowania i komodyfikacji zasobów tak, by służyły nielicznym zamożnym krajom i jeszcze mniej licznym „chuliganom z forsą”. Ci liczniejsi też otrzymują swoją gratyfikację jest nią: dostatek masowej tandety i przemysłowych produktów żywnościowych do skonsumowania oraz masowa infantylizacja, przy czym przerabianie zasobów Ziemi na wskazane formy gratyfikacji, po pierwsze pomnaża doraźne zyski

68 Podaję za: F. Barth, Economy, agency and ordinary lives, „Social Anthropology” 1997, nr 3, s. 234.

69 Masowe połowy obejmujące wszystkie gatunki ryb, z przeznaczeniem na karmę, odebrały miejscowym rybakom możliwość pracy i środki utrzymania. 
głównych aktorów McŚwiata, po drugie utrwala zaprowadzony porządek i go rozszerza. W takim kontekście powstała Wspólna Polityka Rolna. Pytaniem jest czy okaże się ona dla rolnictwa krajów unijnych zabezpieczeniem wystarczająco chroniącym przed dobrodziejstwami McŚwiata? Pytaniem jest też, czy polska „wieś może wygrać z globalizacją”, z McŚwiatem, z restrukturyzacją i jej paradygmatem i czy w Polsce rolnik będzie - wzorem ustaleń unijnych - traktowany jak strażnik i powiernik tradycji kulturowej czy nadal będzie uważany za balast na drodze ku modernizacji i nowoczesności? ${ }^{70}$

\section{McŚwiat w polskim rolnictwie}

Motto: „Po wyprzedaży, przeważnie w obce ręce, większości zakładów przemysłowych i usługowych oraz banków - w polskich rękach pozostały już $w$ zasadzie tylko grunty rolne i lasy. Gdy zostanq sprzedane, a lasy sprywatyzowane - pozostaniemy jak heloci, przed których losem przestrzegał nas Wincenty Witos" - Ludwik Staszyński ${ }^{71}$

Do Polski McŚwiat wkroczył wraz z tak zwaną transformacją ustrojową. Była ona i jest niczym innym jak otwarciem kraju na Rynek, którego zasady porządkują Polskę od przeszło dwóch dekad ${ }^{72}$. Skutek jest aż nadto widoczny m.in.: w likwidacji lub przejęciu przez zagranicznych właścicieli polskiego przemysłu, w przejęciu przez obcy kapitał większości polskich banków, w stale dwucyfrowym bezrobociu i masowej migracji, a ostatnio emigracji. Restrukturyzacja polskiego rolnictwa toczy się w tym samym kierunku, jak dokonana właśnie restrukturyzacja polskiego przemysłu, a „wielkie korporacje dobrze pilnują, by nic nowego pod bokiem im nie wyrosło"73. Pilnują one także swoich interesów w sektorze rolnictwa, w którym gruntowne zmiany zachodzą pod dyktando McŚwiata sugerując, że „chuligani

${ }^{70}$ Nawiązuję do ustaleń i pytania postawionego przez M. Wieruszewską, dz. cyt., s. 90, 92.

${ }^{71}$ L. Staszyński, Zmagania o przetrwanie, Wyd. KMS ResCon, Warszawa 2009, s. 93. Autor odwołuje się do przestrogi W. Witosa „Ile ziemi, tyle będzie i Ojczyzny. Jeśli ziemia zostanie nam spod nóg wydarta, jeśli przejdzie do naszych wrogów, to my pozostaniemy jako heloci i nie będziemy mieli nic więcej do roboty, jak spełniać rolę niewolników"; tamże, s. 84.

72 Istotę transformacji objawia porównanie z dwiema dekadami niepodległej II RP, stworzono wtedy od podstaw polski przemysł, wybudowano port i miasto Gdynię, stworzono polskie banki, koleje, pocztę, LOT, itd. dziś likwidowane, sprzedawane obcemu kapitałowi lub przemieniane w masą upadłościową. W rezultacie Polska już „nie ma (...) suwerenności gospodarczej. (...) Nie u nas zapadają kluczowe decyzje dotyczące przyszłości polskiej gospodarki”; G. Ancyparowicz, Polska gospodarka, s. 28-29.

${ }^{73}$ Tamże. 
z forsą" znaleźli w Polsce dobry polityczny klimat ${ }^{74}$ i oddanych przyjaciół. Zmiany toczą się „w kierunku groźnym nie tylko dla chłopów, ale w ogóle dla Polski"75. Również w rolnictwie realizujemy scenariusz napisany przez promotorów globalizacji i McŚwiata, w tym MFW' ${ }^{76}$, systematycznie pozbawiający nas wszelkiej własności włącznie z gruntami rolnymi i lasami, przygotowywanymi do sprzedaży, a nas samych sposobiący do roli pozbawionych własności i godności „ponowoczesnych chłopów pańszczyźnianych Europy"77. Polska w szybkim tempie kierowana jest na afrykańską ścieżkę, nazywaną rozwojem, zapewniającą nam status kraju i gospodarki podporządkowanej interesom globalnych graczy.

Zaprowadzane zmiany mają osłonę paradygmatów i stosownej retoryki. Jest to wyżej wskazany paradygmat restrukturyzacji i odświeżana teoria modernizacji zakładająca „przemianę wiejskości w miejskość, rolniczości w logikę przemysłową, lokalności w ponadlokalność”, zaś bogaty repertuar zwrotów retorycznych obejmuje takie określenia tradycyjnego chłopskiego gospodarstwa rodzinnego jak: „skansen”, „zaścianek”, „balast transformacji”, dowód „niedorozwoju” i „zapóźnienia cywilizacyjnego”78. Osłona, jaką otrzymuje McŚwiat w polskim rolnictwie ze strony nauki przypomina praktyki stosowane w PRL. Poprzednio odkrywano „prawa” historyczne dziś przyjmuje się stosownie skrojone „paradygmaty”. Wówczas ulubioną była koncepcja profesjonalizacji pracy chłopa, a „pod neutralnym określeniem profesjonalizacji” skrywano „doktrynalnie pożądany rozpad chłopstwa”79. Obecnie nadal doktrynalnie pożądany zanik gospodarstw chłopskich

74 „Dzisiaj zamiany w rolnictwie są związane z polityką bardzo ściśle, bo jaka będzie polityka rolna państwa, taki będzie los polskiej wsi"; słowa ks. J. Tischnera, cytuję za: J. Wilkin, dz. cyt., s. 152.

${ }^{75}$ L. Staszyński, Zmagania o przetrwanie, s. 106.

${ }^{76}$ U progu transformacji „zbierali się najtężsi ekonomiści i byli przerażeni, gdy czytali, co Międzynarodowy Fundusz Walutowy zaleca Polsce. Wiedzieli doskonale, że efektem tego będzie afrykanizacja kraju. Nikt ich jednak nie słuchał, nie chciano dyskutować"; G. Ancyparowicz, Polska gospodarka, s. 29.

77 Wprost pisze o tym Z. Bauman, Życie na przemiat, WL, Kraków 2004, s. 98. Notabene, jesteśmy do nowej roli starannie przygotowani przez nabierającą dopiero rozmachu pedagogikę wstydu mającą raz na zawsze pozbawić nas poczucia godności, własnej wartości i stosownych aspiracji oraz przez popkulturowe infantylizowanie idące w parze z odpowiadającą temu reformą systemu edukacji.

${ }^{78}$ Określenia te podaję za: M. Wieruszewska, dz. cyt., s. 95.

${ }^{79}$ M. Halamska, Funkcje instytucji i organizacji w procesie modernizacji w PRL, IRWiR PAN, Warszawa 1991, s. 149. 
skrywa się pod nowymi fetyszami: restrukturyzacji i koncepcji gospodarstwa farmerskiego, prowadzonego przez obdarzonego mentalnością rynkową farmera ${ }^{80}$, względnie agrobiznesmena. Radykalnej zmianie uległ kontekst gospodarowania i doktryna, bez zmian pozostała krytyka chłopów, dziś za nieumiejętność prowadzenia „gry rynkowej” lub niechęć do niej i za oczekiwanie wsparcia ze strony państwa w owej grze. Antychłopską ideologię marksizmu zastąpiła równie antychłopska ideologia liberalizmu ${ }^{81}$. I to w sytuacji nie istnienia w naszym kraju gospodarki wolnorynkowej. Fakt ten przykrywa retoryka „gry rynkowej”, skrywająca również praktykę selektywnego protekcjonizmu stosowanego wobec silnych graczy McŚwiata, m.in. międzynarodowych sieci handlowych i powrót praktyk regulacyjnych sprzecznych z propagowaną ideologią liberalizmu. Są to: fiskalizm, podtrzymywanie struktur monopolistycznych, ograniczenia dla prywatnej przedsiębiorczości, paraliżowanie gospodarki przez centralny aparat administracyjny ${ }^{82}$. W takich warunkach, trafnie nazwanych „opresyjną wolnością"83, od chłopów żąda się by prowadzili samodzielną i aktywną grę rynkową bez oglądania się na pomoc rządu, kamuflując fakt, iż w rolnictwie urządzanym przez Rynek nie ma miejsca dla gospodarstw chłopskich. Wprost komunikują to twierdzenia o „rozwoju rolnictwa przez upadek rolnictwa” czy „rozwoju wsi poprzez zanik rodzinnych gospodarstw rolnych" ${ }^{34}$. Lecz i one za pomocą słowa „rozwój” skrywają rzeczywistość Rynku. W naszym kraju wymaga on (samo)likwidacji około 1,5 mln małych rodzinnych gospodarstw i przeznaczenie sprzedawanej ziemi rolnej na wielkie majątki ziemskie ${ }^{85}$.

McŚwiatową restrukturyzację wprowadzaną stopniowo i systematycznie ułatwiają przeobrażenia wsi forsowane w okresie PRL. Parcelacja, wraz z poprzedzającą ją eksterminacją okresu II wojny światowej i przesunię-

${ }^{80}$ Wydaje się, że „nowoczesny farmer” to twór „niespotykany w realnym świecie ani w warunkach polskich, ani zachodnich"; I. Bukraba-Rylska, Socjologia wsi polskiej, PWN, Warszawa 2008, s. 377.

${ }^{81}$ K. Gorlach, Socjologia polska wobec kwestii chłopskiej, Universitas, Kraków 1990.

${ }^{82}$ J. Beksiak, Państwo w polskiej gospodarce lat dziewięćdziesiątych XX wieku, PWN, Warszawa 2001.

${ }^{83}$ K. Gorlach, On represiv tolerancje: state and peasant farm in Poland, „Socjologia Ruralis” 1989, z. 1 (29).

${ }^{84} \mathrm{Na}$ te osobliwe twierdzenia zwraca uwagę M. Wieruszewska, dz. cyt., s. 94.

85 „To jest zarówno głupie, jak i karygodne (...) Można by wykorzystać to rozdrobnienie gospodarstw polskich i orientować się na bardzo drogie, pracochłonne rolnictwo ekologiczne"; słowa B. Margueritte, cytuję za: L. Staszyński, Wieś na wstecznym biegu, s. 53. 
ciem kraju o 200 km na zachód ${ }^{86}$, dosłownie zmiotła warstwę „, hreczkosiejów", ziemian gospodarujących w swoich rodowych majątkach, stanowiących materialne zaplecze kultury ziemiańskiej. Zmiana granic ułatwiła też zakładanie PGR-ów na zasiedlanych ziemiach. Ponieważ nie powiodły się początkowe usiłowania zniszczenia chłopskich gospodarstw, zastosowano ich „represyjne tolerowanie" ${ }^{87}$. W stworzonych warunkach zasadą działania tradycyjnego chłopskiego gospodarstwa nie była „maksymalizacja zysku, lecz minimalizacja ryzyka"88, obliczona na trwanie. Polityka rolna po 1989 roku prowadzi do takich przekształceń własnościowych, które w roli gospodarza gruntów rolnych w Polsce obsadzą właścicieli latyfundiów, nierzadko obcokrajowców. Po pierwsze, z dnia na dzień rolnictwo, regulowane dotąd przez państwo, poddano mechanizmowi rynkowemu, w niewielkim tylko stopniu korygowanemu przez politykę rolną ${ }^{89}$. Tak nagrodzono chłopów za przetrwanie komunizmu ${ }^{90}$. W rezultacie rynkowej „terapii” część rolników ograniczyła produkcję i poszukała dochodów poza rolnictwem, a jedna trzecia zaczęła się utrzymywać z transferów socjalnych ${ }^{91}$. Wśród szczególnie skrzywdzonych znaleźli się pracownicy Państwowych Gospodarstw Rolnych transformowanych na mocy ustawy z 1991 roku, która doprowadziła do całkowitego bankructwa połowę z nich ${ }^{92}$. Dzieła zniszczenia dopełnił „masowy import i przemyt napojów alkoholowych” powodujący upadek krajowego gorzelnictwa stanowiącego źródło „znacznych dochodów dla wielu PGR-ów" ${ }^{\prime 93}$. Urynkowienie polskiego rolnictwa i zniszczenie PGR-ów gruntownie spolaryzowało rolników. Faktu tego nie zmieniła zdecydowana poprawa sytuacji producentów rolnych w Polsce po 2004 roku, możliwa dzięki funduszom związanym ze Wspólną Polityką Rolną ${ }^{94}$ Ten „parasol

86 „Polskę przesunięto, w sensie fizycznym, o ponad 200 kilometrów na zachód - jak oddział wojska”. N. Davis, Boże igrzysko. Historia Polski, Znak, Kraków 1991, s. 606.

${ }^{87}$ Jest to modyfikacja określenia K. Gorlacha „represyjna tolerancja”.

${ }^{88}$ L. Kocik, Między przyrodq..., s. 106.

${ }^{89}$ J. Wilkin, $d z$. cyt., s. 152. Chłopskie gospodarstwa z dnia na dzień zostały popchnięte do przejścia od samowystarczalności do produkcji rynkowej; L. Kocik, Między przyrodą..., s. 107.

90 L. Kocik, Między przyrodą..., s. 120. Notabene, świadczy to o nagradzających i o wartości, jaką miało dla ich gospodarstwo chłopskie.

${ }_{91}$ J. Wilkin, dz. cyt., s. 141.

92 W. Kieżun, Patologia transformacji, Wyd. Poltext, Warszawa 2012, s. 158.

93 L. Staszyński, Bezdroża prywatyzacji - fakty i opinie, Książka Polska, Warszawa 1997; cytuję za: W. Kieżun, dz. cyt., s. 158.

94 „W okresie poakcesyjnym dochody realne producentów rolnych w Polsce wzrosły o ponad 110\%"; J. Wilkin, dz. cyt., s. 152. 
ochronny" objął, bowiem tylko tych, którzy przetrwali jako producenci rolni, co więcej został on rozłożony nad naszym rolnictwem dekadę po tym jak przeniknęły do niego i zaczęły go transformować międzynarodowe korporacje $^{95}$. Owe „ekspozytury instytucji globalnych” ${ }^{96}$ zaopatrując rolników w nowoczesne środki produkcji i skupując wytwarzane przez nich produkty rolne wiązały rolników „z wielkimi sieciami handlu hurtowego i detalicznego", włączając gospodarstwa produkujące na rynek w struktury rynku światowego, czego wyrazem stał się „szybki wzrost eksportu produktów rolno-spożywczych"97. Rzeczone gospodarstwa integrują „się coraz silniej z globalnymi strukturami agrobiznesu"98, tym samym utrwalając te struktury w naszym kraju. Jednak pozycja polskich gospodarstw jest w strukturze agrobiznesu słaba, ponieważ nie wypracowali oni wielu form współdziałania między sobą ${ }^{99}$. Zatem, integracja, o której mowa służy najsilniejszym ogniwom agrobiznesu, czyli globalnym korporacjom, głównym podmiotom McŚwiata.

Przekształcenia związane ze sprzedażą gruntów rolnych polegające na tworzeniu latyfundiów pokazują, że w naszym kraju realizowany jest McŚwiatowy model rolnictwa znany z krajów trzeciego świata. Tym przekształceniom przygląda się PSL, partia z nazwy ludowa, deklarująca na swoim Kongresie w 1993 roku: „zdecydowanie opowiadamy się przeciwko powrotowi do kapitalistycznego rolnictwa ziemiańskiego" ${ }^{100}$, jakby chodziło tylko to, by właścicielami wielkich majątków nie byli ziemianie. Ze swej strony powstawanie latyfundiów pozostaje w sprzeczności z 23 art. Konstytucji RP orzekającym, że podstawą ustroju rolnego państwa jest gospodarstwo rodzinne. Zaradzono temu szybko i łatwo, przyjmując 11 kwietnia 2003 r. ustawę mocą, której „za rodzinne uważa się gospodarstwo rolne prowadzone przez rolnika indywidualnego, w którym łączna powierzchnia

95 Moderatorem zmian w naszym rolnictwie stały się „nowoczesne firmy, często międzynarodowe, powiązane z rolnictwem zarówno na etapie zaopatrywania go w środki produkcji, jak i w fazie przetwórstwa oraz dystrybucji; J. Wilkin, dz. cyt., s. 141.

${ }^{96}$ Określenie K. Gorlacha, Świat na progu domu. Rodzinne gospodarstwa rolne $w$ Polsce w obliczu globalizacji, Wyd. UJ, Kraków 2001, s. 16.

${ }^{97}$ J. Wilkin, dz. cyt., s. 143.

98 Tamże.

99 Tamże. Na kwestię niskiego stopnia zorganizowania chłopów nie umiejących wykorzystać „możliwości, jakie daje im demokracja” zwraca także uwagę L. Staszyński, Wieś na wstecznym biegu, s. 78.

100 Cytuję za: L. Staszyński, Wieś na wstecznym biegu, s. 58. 
użytków rolnych nie jest większa niż 300 ha”101. Ponadto ustawa „dopuszcza możliwość powiększania obszaru istniejących gospodarstw nawet do 500 ha drogą zakupu gruntów z zasobów państwowych", co rodzi pytanie, komu ona służy „w kraju, w którym indywidualne gospodarstwo rolne posiadało w 2008 r. przeciętnie 8,8 ha?"102 Otóż, ustawa służy McŚwiatowej restrukturyzacji, jej krajowym i zagranicznym beneficjentom i głównym rozgrywającym, czyli globalnym korporacjom. Interes tych osób i gremiów znaczy więcej niż sens zapisu Konstytucyjnego oraz regulacje prawne i praktyka stosowane w krajach UE, gdzie od 1996 r. nawet 65 hektarowego gospodarstwa nie uznaje się za rodzinne, a za kryterium kwalifikacji gospodarstwa jako rodzinnego przyjmuje bezpośrednią pracę właściciela i jego rodziny i to, że uzyskiwane dochody stanowią podstawę ich utrzymania ${ }^{103}$. Wymownym faktem jest, że w Polsce parokrotnie ${ }^{104}$ wnoszono projekty podobnych ustaw, zawsze jednak bez skutku. McŚwiatowa restrukturyzacja urządza nasze rolnictwo, ponieważ ma tu swoich wpływowych orędowników i beneficjentów. Sprzyjają jej zaniechania umożliwiające proceder nielegalnego wykupu wielkich połaci gruntów rolnych przez obcokrajowców i przez spółki zarejestrowane w Polsce, których udziałowcami są obcokrajowcy ${ }^{105}$. Wykup może poprzedzać dzierżawa ziemi po PGR-owskiej, odbywa się on też za pośrednictwem przetargów organizowanych przez Agencję Nieruchomości Rolnej, na których podbija się cenę i płaci gotówką ${ }^{106}$ w sytuacji, gdy

101 Tamże, s. 4. W myśl ustawy „do uznania za rodzinne wystarcza (...) osobiste prowadzenie gospodarstwa do 300 ha, a nie osobista praca rolnika oraz członków jego rodziny”; tamże.

102 Tamże, s. 5.

103 Tamże, s. 55.

104 Miało to miejsce w latach 1995, 1998, 1999; tamże.

105 Na przykład spółka PER LA, w której pięciu członków zarządu to obywatele Niemiec, jest jednym z największych właścicieli gruntów rolnych w gminie Kozielice. Skupuje ona grunty najwyższej klasy, tzw. czarnoziemy zachodniopomorskie, w powiecie pyrzyckim; T. Duklanowski, N. Michalska, Niemieckie słupy na polskiej ziemi, „Gazeta Polska”, 19-26 grudnia 2012, s. 7.

106 Jednym ze sposobów jest pobranie przez osobę podstawioną kredytu za granicą pod hipoteczny zastaw ziemi; istnieją też specjalne fundusze w Niemczech, Danii i innych krajach dla kupujących ziemię w Polsce; por.: T. Duklanowski, N. Michalska, Niemieckie słupy..., s. 7. Transakcja może przebiegać tak: „Zostało jeszcze jakieś 300 tyś. ha, ale my nie mamy szansy na ich kupienie. Ostatnio jak byłem na przetargu, przyszedł Duńczyk ze swoim „słupem” i powiedział łamaną polszczyzną „wy iść do domu, ja płacić 40 tyś. za hektar” (...). Rolnicy opowiadają, że człowiek, którego znają i który mieszka na terenie ich gminy, jedzie na przetarg na rowerze, bo nie ma innego środka lokomocji, a następnie licytuje setki hektarów w cenie po 30-40 tyś za ha (...) po czym wsiada na rower i odjeżdża. To jest po prostu „słup” działający na czyjeś zlecenie. I niestety to są sytuacje nagminne"; T. Duklanowski, Jak rzq̨d łata budżet, oddając polska ziemię, „Gazeta Polska”, 16 stycznia 2013, s. 11. Po akcjach protestacyjnych polskich rolników 
polskim rolnikom coraz trudniej jest uzyskać kredyt na zakup gruntów ${ }^{107}$. Nabywanie polskich gruntów rolnych to doskonały interes nie tylko z racji ceny, jest to także pewna inwestycja na przyszłość, w sytuacji wzrostu na całym świecie cen użytków rolnych i cen żywności ${ }^{108}$. Doraźnie, zakup daje możliwość uzyskania sporych dochodów, także spółkom zajmującym się produkcją rolną, dzięki programom rolno-środowiskowym „w ramach, których można dostać 800 zł dopłaty do każdego hektara”109. Mimo nacisków ze strony polskich rolników rozwiązania stosowane we Francji, Niemczech, Danii, gdzie grunty rolne może w praktyce kupić tylko rodzimy rolnik nie są w naszym kraju naśladowane ${ }^{110}$.

Wielkie gospodarstwa i przedsiębiorstwa rolne ${ }^{111}$ - rezultat prowadzonej u nas restrukturyzacji - zwykle realizują sprzeczny z promowanym w UE modelem rozwoju zrównoważonego, agroindustrialny model rolnictwa zorientowanego na maksymalną produktywność i "fabrykowanie” żywności, nawiązujący do technologii „kukurydza - soja - beton”112, z tą modyfikacją, że i kukurydza i soja mogą być dziś GMO. Ponieważ latyfundia będące dziełem Rynku mają przynosić zysk jego głównym aktorom, nie jest istotne, że zorientowanie ich produkcji na eksport nie zapewni krajowi dostatku żywności, a wykorzystywanie pasz GMO radykalnie obniża jej jakość. Osobliwością krajową - i wkładem w McŚwiatową restrukturyzację - jest definiowane tych latyfundiów, jako gospodarstw rodzinnych, co daje im przywileje i korzyści przewidziane w UE dla tego typu gospodarstw. A chłopskie gospodarstwa - uważane, jak w PRL, za przeszkodę w budowaniu „nowoczesnego” rolnictwa - są stopniowo eliminowane, po myśli

z województwa zachodniopomorskiego, CBA wszczęło w tej sprawie śledztwo, odmawia jednak podania skali procederu.

107 Bank Gospodarki Żywnościowej (BGŻ), który miał przejść na własność polskich banków spółdzielczych i wspierać nasze rolnictwo, ostatecznie przeszedł całkowicie pod kontrolę holenderskiej grupy Rabo.

${ }^{108}$ Ma ona też aspekt polityczny, gdy kupującymi ziemię, na zachodzie i północy kraju, są Niemcy.

109 T. Duklanowski, N. Michalska, Niemieckie słupy..., ns. 7.

110 Kraje te uniemożliwiając, w praktyce, nabywanie gruntów rolnych przez cudzoziemców rozumieją doskonale, że własność ziemi, to kwestia własności terytorium państwa.

111 Powstało obszarnictwo nieznane „już niemal w ogóle w innych krajach Unii Europejskiej"; L. Staszyński, Zmagania o przetrwanie, s. 89.

112 Ta technologia stosowana m.in. w Francji w latach 70. XX wieku zakładała likwidację łąk, uprawę kukurydzy, import soji i hodowanie zwierząt w nowoczesnej, wybetonowanej oborze; J. Bove, F. Dufour, Świat nie jest towarem, Wyd. Andromeda, Gdańsk 2002, s. 106-107. 
krajowych i zewnętrznych grup interesu ${ }^{113}$. W McŚwiecie nie przewidziano miejsca dla gospodarstw chłopskich, nie ma go więc w Polsce. Urządzanie naszego rolnictwa wedle zasad McŚwiata już obecnie spowodowało zmniejszenie produkcji w różnych branżach, obniżenie kultury rolnej i zubożenie właścicieli małych i średnich gospodarstw, ponieważ „drobnotowarowa produkcja rolna nie interesuje obecnego dużego przemysłu przetwórczego"114. Ma miejsce sytuacja, gdy „rynek już prawie nie przyjmuje wytworów ich pracy, czego nigdy wcześniej nie było"115. Jest to, bowiem Rynek masowej produkcji żywności, jako towaru-rzeczy, dla jej masowej konsumpcji lub masowego niszczenia i dla maksymalnego zysku minimalnej liczby podmiotów.

Podobnie McŚwiatowy przemysł żywności rozwija się w Polsce w najlepsze, z tymi samymi skutkami, jak w innych krajach, czyli produkcją żywności niskiej jakości, wytwarzanej przy zastosowaniu m.in.: modyfikowanej skrobi, konserwantów, wypełniaczy, polepszaczy, utrwalaczy, a także soli drogowej ${ }^{116}$. Rozwojowi tego przemysłu w naszym kraju sprzyja zaniżanie norm jakości, planowana likwidacja licznych laboratoriów sanepidów, brak kompleksowej kontroli żywności, prawo nieprzewidujące konfiskaty mienia i likwidacji firm dokonujących fałszerstw i nadużyć przy produkcji żywności ${ }^{117}$. Rozwojowi przemysłu żywności sprzyja też przyjęta niższa stawka podatku VAT na produkty koncernów w porównaniu ze stawką przyjętą dla żywności naturalnej, co w sposób systemowy faworyzuje te pierwsze, przyczyniając się do wypierania przez nie żywności naturalnej szczególnie $\mathrm{z}$ diety uboższych segmentów społeczeństwa ${ }^{118}$.

O postępach w urządzaniu polskiego rolnictwa przez McŚwiat świadczy także sposób rozwiązania w Polsce kwestii roślin genetycznie modyfikowanych. Dziwny z pozoru kontredans wokół GMO - przyjęcie przez rząd

113 L. Staszyński, Wieś na wstecznym, s. 78. A „wszystko, co szkodzi wsi - uderza pośrednio w całe państwo; wszystko co wieś wspiera - jest korzystne dla obecnego i dla następnych pokoleń Polaków"; tamże, s. 78.

114 Tamże, s. 34, 78.

115 Tamże, s. 34.

116 Prowadzone śledztwa nadal nie ujawniły nazw firm sól tę stosujących.

117 Instytucje państwowe takie, jak Państwowa Inspekcja Sanitarna, Inspekcja Handlowa, Inspekcja Weterynaryjna nie są wstanie przeciwdziałać praktykom koncernów spożywczych i wielkich sieci handlowych, których hurtownie i magazyny często znajdują się za granicą.

118 Notabene, stopniowe zastępowanie naturalnej żywności przez masowe produkty przemysłu żywności pozbawia kolejne pokolenia zdolności rozpoznawania jakości spożywanego pokarmu. 
specjalnego, łatwego do uchylenia, rozporządzenia wprowadzającego zakaz stosowania materiału siewnego GMO, które nie przewiduje zwiększenia środków na kontrolę jego przestrzegania i idzie w parze z brakiem zakazu sprzedaży nasion GMO, przy jednoczesnym ograniczeniu dostępu do tradycyjnych nasion ${ }^{119}$ - jest zrozumiały, gdy pamiętamy, że ok. 80 procent centrali nasiennych w Polsce pozostaje w rękach firmy Cargill, spółki-córki koncernu Monsanto. I na tym przykładzie widać, że przy braku sprzeciwu ze strony rządu stajemy się europejskim „żerowiskiem” antynarodowych globalnych korporacji. Wobec przyjęcia ustawy zakazującej upraw GMO w takich krajach unijnych jak Niemcy i Francja ${ }^{120}$ sytuuje to nas w roli unijnych peryferii skrywających nie tyle „brudny sekret kapitalizmu”121, ile brudne interesy McŚwiata.

U progu zmian James Goldsmith przestrzegał: „musicie chronić swoje rolnictwo, bo jeśli nie - Polska zginie"122. Radę zignorowaliśmy wydając polską wieś i rolnictwo na łup McŚwiatowych „chuliganów z forsą”. Skutki już dziś są widoczne. Stworzone warunki prowadzą do likwidacji kolejnych chłopskich gospodarstw rodzinnych, i tak realizuje się zadanie niewykonane w PRL, oraz do powstawania wielkich majątków ziemskich, co przeczy przeprowadzonej w PRL parcelacji. Wielkie majątki były złem, gdy były w posiadaniu rodowych właścicieli, należało je parcelować i krzywdzie chłopskiej zaradzić. Obecnie nie ma mowy o krzywdzie, lecz o nierentowności chłopskich gospodarstw, co sprzyja dalszej zmianie właściciela polskich gruntów rolnych. Restrukturyzacja prowadząca do likwidacji

119 Międzyzwiązkowy Komitet Protestacyjny Rolników Województwa Zachodniopomorskiego wyraził sprzeciw wobec próby zalegalizowania upraw GMO mocą nowej ustawy o nasiennictwie, która uchyla zakaz obrotu nasionami GMO; podkreślono, że gwarancję uchronienia Polski przed GMO może dać tylko zabraniająca tego ustawa.

${ }^{120}$ We Francji mówi się i o szkodliwości GMO i o jej niskiej jakości; rolnicy propagujący rolnictwo jakościowe nazywają uprawy GMO barbarzyńskimi, prostackimi, niecywilizowanymi.

121 „Brudny sekret kapitalizmu” to degradowanie środowiska w krajach niezdolnych do zapobieżenia temu, przy jednoczesnym przerzucaniu na nie kosztów ochrony środowiska: I. Wallerstein, Koniec świata jaki znamy, Scholar, Warszawa 2004.

122 Cytuję za: L. Staszyński, Wieś na wstecznym biegu, s. 6. Ostrzeżenia płynęły od ekonomistów tej miary, jak J. K. Galbreith, Milton Friedman, apelowali oni: „W Europie Wschodniej (...) następuje świadoma rujnacja gospodarki pod dyktando MFW, popychanie do wolnego rynku za wszelką cenę (...). Nie zwracać ziemi byłym właścicielom (...). Nie oddawać fabryk załogom, bo syndykalizm jest mało wydajny (...). Wyprzedawać cudzoziemcom i własnym nabywcom (...). Jest to świadome imperialistyczne dążenie do zagarnięcia jak najszybciej atutów gospodarczych regionu i zniszczenie reszty, by przekształcić te kraje w zacofane neokolonie, polując na wielkie zyski"; tamże, s. 71. 
chłopskich gospodarstw rodzinnych zmiecie tym razem chłopów i pozostałości ich kultury ${ }^{123}$. Na przygotowywany teren stopniowo wkracza kapitał, często obcy, tworząc „fabryki żywności”, które produkując dla przemysłu żywności stają się zapleczem antynarodowych korporacji multiplikujących swoje zyski na nowym „żerowisku”. Na polskiej - dotąd - wsi wraz z nowym właścicielem zwycięży kapitał nad pracą, i polską kulturą, a obecni właściciele ziemi staną się lokalną bądź wędrowną, migrującą za granicę, siłą roboczą. W ten sposób przekształcenia rozpoczęte jeszcze w PRL a dokończone przez restrukturyzację doprowadzą do całkowitej zmiany właścicieli gruntów rolnych w Polsce, wraz z pozostałymi skutkami transformacji doprowadzi to do zmiany gospodarzy kraju ${ }^{124}$.

Podejmowane są jeszcze różne formy obrony wsi i chłopskich gospodarstw przed Rynkiem, chociaż niektórzy „mieszkańcy wsi cechują się wysokim poziomem poczucia deprywacji” i są „przekonani o braku perspektyw dalszego rozwoju wsi"125. Jednym z realizowanych pomysłów jest tworzenie enklaw lokalnej żywności ${ }^{126}$, które wszelako powinny się bronić przed przekształceniem w rolnicze skanseny lokalnego produktu żywnościowego ${ }^{127}$. Rozwiązaniem chroniącym rodzinne gospodarstwo chłopskie może być model rozwoju zrównoważonego, warunkiem jego realizacji jest „współ-

${ }^{123}$ W PRL: „częściowa kolektywizacja wsi i agresywne wypieranie tradycyjnych wartości przez socjalistyczny porządek wyraźnie naruszyły wielowiekową transmisję zwyczajów i mechanizm powielania chłopskiej kultury materialnej"; L. Kocik, Anomia moralno-obyczajowa wsi polskiej, [w:] Kondycja moralna społeczeństwa polskiego, pod red. J. Mariańskiego, WAM, Kraków 2002, s. 81; zmiany nie objęły sfery gospodarki, lecz właśnie sferę obyczaju, stylu życia i konsumpcji: „powszechny na wsi „”pęd do nowoczesności”"' został skierowany głównie na sferę wyposażenia zagrody oraz konsumpcji rodzinnej, inwestowanie w pozarolniczą przyszłość potomstwa, nabywanie wytworów i urządzeń stanowiących elementy prestiżu społecznego, czyli na dziedziny niezwiązane z funkcjonowaniem gospodarstwa"; L. Kocik, Między przyro$d q$..., s. 102; „styl kultury materialnej (architektura, urządzenie wnętrz, ubranie, odżywianie) najbardziej widoczny i najszybciej przejmowany - zmierza również zdecydowanie we wszystkich grupach chłopsko-rolniczych w kierunku wzorów miejskich" pisała E. Jagiełło-Łysiowa, Elementy stylów życia ludności wiejskiej. Próba diagnozy społecznej i prognozy, [w:] Styl życia. Przemiany we współczesnej Polsce, pod red. A. Sicińskiego, PWN, Warszawa 1978, s. 111.

${ }^{124}$ Po ponad dwudziestu latach od jej rozpoczęcia transformacja wygląda jak przemyślana i systematycznie realizowana strategia wymiany gospodarza kraju.

125 A. Sadowski, Kapitał społeczny mieszkańców wsi województwa podlaskiego, [w:] Socjologia jako służba..., s. 103.

${ }_{126}$ T. Adamski, K. Dzwonkowska, K. Gorlach, A. Pilichowski, P. Starosta, Wiedza w rozwoju zrównoważonym wsi, Wydawnictwo UJ, Kraków 2007.

127 Czym może skutkować takie przekształcenie, pokazuje przykład afrykańskich Masajów i ich tradycyjnego pasterstwa, dziś stanowiącego bardziej atrakcję turystyczną niż typ lokalnej gospodarki. 
praca pomiędzy przedstawicielami świata nauki i lokalnych społeczności, władz państwowych oraz organizacji pozarządowych"128. Przyjmowaną formą obrony jest też wycofanie z rynku i retradycjonalizacja, jej przeciwieństwem są zorganizowane protesty rolnicze, których kolejne fale przetaczają się przez kraj ${ }^{129}$. Szczególnie protesty pierwszej fali spowodowały zmianę polityki rolnej na korzyść rolników. Pod ich naciskiem utworzono: „Agencję Rynku Rolnego, podjęto decyzje o sposobie prywatyzowania ziemi pozostałej po państwowych gospodarstwach rolnych, polegającej na przyznaniu rolnikom kredytów w celu jej dzierżawy lub wykupienia"130. Późniejsze protesty wymusiły tylko korekty polityki rolnej, a większości postulatów nie zrealizowano ${ }^{131}$. Sprawą otwartą jest los obecnie wysuwanych postulatów ${ }^{132}$. Pomocą w obronie gospodarstw chłopskich przed McŚwiatem mogłaby być odrodzona spółdzielczość rolnicza ${ }^{133}$.

Ostoją polskiej wsi i rolnictwa są chłopskie gospodarstwa rodzinne, są one także zaporą przed rolnictwem urządzanym przez McŚwiat ${ }^{134}$, last but not least chłopska własność gruntów rolnych zabezpiecza terytorium państwa. W interesie kraju i nas wszystkich jest rolnictwo osadzone

128 T. Adamski, K. Dzwonkowska, K. Gorlach, A. Pilichowski, P. Starosta, Wiedza w rozwoju..., s. 79.

129 Pierwszą była fala protestów z lat 1989-1993, drugą protesty z lat 1997-2001, w latach 1993-1997 protesty zażegnało „zaproponowanie preferencyjnych kredytów dla rolników, dokapitalizowanie BGŻ, wprowadzenie dopłat do paliwa rolniczego oraz rent i emerytur rolniczych, a także ograniczenia importu towarów rolnych"; G. Foryś, Z badań nad protestami rolniczymi w Polsce, „Wieś i Rolnictwo” 2008, nr 4, s. 17. A dokapitalizowany BGŻ stał się niedługo własnością obcego kapitału!

${ }^{130}$ Tamże, s. 24.

131 Tamże, s. 25.

${ }^{132}$ W styczniu 2013 r. Międzyzwiązkowy Komitet Protestacyjny Rolników Województwa Zachodniopomorskiego przedłożył rządowi m.in. postulaty: objęcia tarczą antykorupcyjną procesu gospodarowania gruntami, wstrzymania prywatyzacji spółek sektora rolno-spożywczego toczącej się obecnie bez czynnego udziału rolników, wprowadzenie ustawy zakazującej upraw GMO w kraju.

133 Po 1898 r. polityka finansowa państwa w krótkim czasie doprowadziła do prywatyzacji przedsiębiorstw spółdzielczych: „w obce ręce przeszło (...) szereg najlepszych, najnowocześniejszych zakładów mięsnych, mleczarskich, tłuszczowych, cukierniczych, cukrowni, zakładów tytoniowych, spirytusowych, itp."; por.: L. Staszyński, Zmagania o przetrwanie, s. 96. Stoi to w jaskrawej sprzeczności z polityką państwa w latach międzywojennych aktywnie wspierającą spółdzielczość rolniczą.

${ }^{134}$ Wygrana Rynku z polską wsią byłaby ostatnim aktem przekształcania kraju i jego zasobów w towar do skonsumowania przez „chuliganów z forsą”. 
na chłopskich gospodarstwach rodzinnych ${ }^{135}$. Nic nie straciły na aktualności słowa Juliana Ursyna Niemcewicza „Zaklinam, chciejcież rolnictwo szanować: W mieczu i pługu są Polaków siły"136.

\section{BIBLIOGRAFIA}

- Adamski T., Dzwonkowska K., Gorlach K., Pilichowski A., Starosta P., Wiedza w rozwoju zrównoważonym wsi, Wydawnictwo UJ, Kraków 2007.

- Adamski T., Gorlach K., Koncepcja rozwoju neoendogennego, czyli renesans znaczenia wiedzy lokalnej, [w:] Socjologia jako służba społeczna, pod red. K. Gorlacha, M. Niezgody, Z. Seręgi, Wydawnictwo UJ, Kraków 2007.

- Ancyparowicz G., Polska gospodarka jest jak lokomotywa opanowana przez zbieraczy złomu, (rozmowa z J. i M. Karnowskimi), „Sieci”, 18-24 marca 2013.

- Barber B., Dżihad kontra McŚwiat, Muza, Warszawa 1997.

- Barth F., Economy, agency and ordinary lives, „Social Anthropology” 1997, nr 3.

- Bauman Z., Życie na przemiat, WL, Kraków 2004.

- Beksiak J., Państwo w polskiej gospodarce lat dziewięćdziesiątych XX wieku, PWN, Warszawa 2001.

- Bove J., Dufour F., Świat nie jest towarem, Wyd. Andromeda, Gdańsk 2002.

- Bukraba-Rylska I., Socjologia wsi polskiej, PWN, Warszawa 2008.

- Davis N., Boże igrzysko. Historia Polski, Znak, Kraków 1991.

- Duklanowski T.,Jak rząd łata budżet, oddając polską ziemię, ,Gazeta Polska”, 16 stycznia 2013.

- Duklanowski T., N. Michalska, Niemieckie słupy na polskiej ziemi, „Gazeta Polska”, 19-26 grudnia 2012.

- Foryś G., Z badań nad protestami rolniczymi w Polsce, „Wieś i Rolnictwo” 2008, nr 4.

- Gorlach K., On represiv tolerancje: state and peasant farm in Poland, „Socjologia Ruralis” 1989, z. 1 (29).

- Gorlach K., Socjologia obszarów wiejskich. Problemy i perspektywy, Wydawnictwo Scholar, Warszawa 2004.

- Gorlach K., Socjologia polska wobec kwestii chłopskiej, Universitas, Kraków 1990.

- Gorlach K., Świat na progu domu. Rodzinne gospodarstwa rolne w Polsce w obliczu globalizacji, Wyd. UJ, Kraków 2001.

- Halamska M., Funkcje instytucji i organizacji w procesie modernizacji w PRL, IRWiR PAN, Warszawa 1991.

135 Kluczową jest pomoc ze strony państwa, którego obecne poczynania i zaniechania czynią realnym dalsze popadanie w niewolę ubóstwa całych odłamów społeczeństwa i likwidację polskiej wsi i rolnictwa, zapewniającego samodzielność żywnościową kraju.

136 J. U. Niemcewicz, Śpiewy historyczne, Universitas, Kraków 2002, s. 13. 
- Jagiełło-Łysiowa E., Elementy stylów życia ludności wiejskiej. Próba diagnozy społecznej i prognozy, [w:] Styl życia. Przemiany we współczesnej Polsce, pod red. A. Sicińskiego, PWN, Warszawa 1978.

- Kieżun W., Patologia transformacji, Wyd. Poltext, Warszawa 2012.

- Kocik L., Anomia moralno-obyczajowa wsi polskiej, [w:] Kondycja moralna społeczeństwa polskiego, pod red. J. Mariańskiego, WAM, Kraków 2002.

- Kocik L., Między przyrodą, zagrodq̨ i społeczeństwem, Wydawnictwo UJ, Kraków 2000.

- Korten D., When the Corporation Rule the World, Kumarin, New York 1995.

- Niemcewicz J. U., Śpiewy historyczne, Universitas, Kraków 2002.

- Perkins J., Hitman. Wyznania ekonomisty od brudnej roboty, Studio Emka, Warszawa 2006.

- Romaniszyn K., Globalizacja - proces żywiołowy czy sterowany?, [w:] Problemy cywilizacyjne naszej współczesności, pod red. J. Gąssowskiego, J. Goćkowskiego, K. Machowskiej, Akademia Humanistyczna, Pułtusk 2007.

- Sadowski A., Kapitał społeczny mieszkańców wsi województwa podlaskiego, [w:] Socjologia jako służba społeczna, pod red. K. Gorlacha, M. Niezgody, Z. Seręgi, Wydawnictwo UJ, Kraków 2007.

- Sklair L., Sociology of the Global System, Prentice Hall, London 1995.

- Staszyński L., Bezdroża prywatyzacji - fakty i opinie, Książka Polska, Warszawa 1997.

- Staszyński L., Wieś na wstecznym biegu, Wyd. KMS ResCon, Warszawa 2010.

- Staszyński L., Zmagania o przetrwanie, Wyd. KMS ResCon, Warszawa 2009.

- Szewczyk J., Krwiożercze bliźniaki rządzq światem, „W Sieci”, 4-10 luty 2013.

- Wallerstein I., Koniec świata jaki znamy, Wydawnictwo Scholar, Warszawa 2004.

- Wieruszewska M., Kryzys - mit - intuicja. Refleksja nas wsiq - niekoniecznie naukowa, [w:] Socjologia jako służba społeczna, pod red. K. Gorlacha, M. Niezgody, Z. Seręgi, Wydawnictwo UJ, Kraków 2007.

- Wilkin J., Polskie rolnictwo i wieś w globalnej przestrzeni - szanse, zagrożenia i mechanizmy dostosowawcze, [w:] Powiązania zewnętrzne. Modernizacja Polski, pod red. W. Morawskiego, Wolters Kluwer, Warszawa 2012.

\section{Agriculture in THE MCWORLD}

This chapter draws upon Beniamin Barber's concept of McWorld, understood as an omnipotent Market organized mainly by and for the transnational global corporations, with crucial support of globilizing institutions such as the WB, the IMF, the WTO, and the GATT. It coins and develops a thesis holding that agriculture all over the world has been seized by McWorld, that resulted in creation of latifundum, in transformation of peasants into rural workers, and in the commodification of food, processed in food industry and treated as merely market item. In this chapter special attention has been paid to the issue of the McWorld's impact on the Polish agriculture. The undertaken analysis leads to the conclusions that despite the European Union's policy of agriculture protection against the Market the McWorld's rules constantly transform Polish agriculture and deadly threaten family farming in Poland. 